\title{
Galvanostatic Pulse Plating of PtRu Nanoparticles for Direct Methanol Fuel Cells
}

\author{
Yu-Chi Hsieh, Yung-Jean Lu, Pu-Wei Wu, Yun-Min Chang, and Yu-Fan Chiu \\ Department of Materials Science and Engineering, National Chiao Tung University, \\ Hsin-Chu 300, Taiwan, ROC
}

\begin{abstract}
A galvanostatic pulse electrodeposition technique of preparing nanoparticulate PtRu electrocatalyst for direct methanol fuel cells has been demonstrated. After extensive cyclic voltammetric analysis, we determined the optimized parameters for the methanol oxidation to be current on-time on $50 \mathrm{~ms}$, current off-time of 400 $\mathrm{ms}$, current density of $50 \mathrm{~mA} / \mathrm{cm}^{2}$, and total charge of $8.0 \mathrm{C} / \mathrm{cm}^{2}$. In addition, the catalyst loading was measured at $68 \mu \mathrm{g} / \mathrm{cm}^{2}$, resulting in a mass activity of $213 \mathrm{~mA} / \mathrm{Pt}$. $\mathrm{mg}$. The composition for the nanoparticles was confirmed as $\mathrm{Pt}_{65} \mathrm{Ru}_{35}$. High-magnification images on the specimen indicated fine particles in 4-20 nm with uniform distributions.
\end{abstract}

$\mathrm{PtRu}$ has attracted considerable attention as an anode electrocatalyst for direct methanol fuel cells [1]. Recently, the research objective for the PtRu has concentrated on the synthesis in nanoparticulate form with desirable atomic distributions in both bulk and surface states. Conventional synthetic route involves chemical reduction techniques which unfortunately require post-treatments to remove surfactants and reaction products. This engenders results in some difficulties in precise composition control [2,3]. In contrast, electrodeposition is recognized to produce PtRu directly, albeit with a reduced coulombic efficiency [3-6]. In this work, we adopt a pulse galvanostatic deposition technique to fabricate the $\mathrm{PtRu}$ nanoparticles on carbon clothes and evaluate their methanol oxidation abilities. In addition, morphologies, compositions, and phase analysis of the as-prepared PtRu particles were conducted using Transmission Electron Microscope (TEM), Inductively Coupled Plasma Mass Spectrometry (ICP-MS), and X-ray Diffraction (XRD).

A carbon cloth was used as the starting substrate in this study. Prior to the electrodeposition, the carbon cloth was coated with an ink dispersion which was prepared 
by mixing $5.0 \mathrm{mg}$ Nafion solution $(5.0 \mathrm{wt} \%$ ) and $8.0 \mathrm{mg}$ commercial carbon powders (Vulcan XC-72R) in $5.0 \mathrm{ml} 99.5 \mathrm{wt} \%$ ethanol for $30 \mathrm{~min}$. The ink dispersion was deposited carefully on a $2 \times 2 \mathrm{~cm}^{2}$ carbon cloth which was kept at $80^{\circ} \mathrm{C}$ atop a hotplate to evaporate the residual ethanol. The coating of the ink dispersion effectively reduced the surface area, porosity, and capacitance of the carbon cloth. Afterwards, an electrochemical treatment was adopted by imposing multiple voltammetric cyclings on the carbon cloth at potential between -0.2 and $+1.1 \mathrm{~V}(\mathrm{vs} . \mathrm{Ag} / \mathrm{AgCl})$ at a scan rate of 50 $\mathrm{mV} / \mathrm{s}$ in an electrolyte of $0.5 \mathrm{M}$ sulfuric acid. The purpose for this step was to homogenize the pretreated carbon cloth and expose a larger surface area. For subsequent pulse electrodeposition, the electrolyte was prepared by mixing proper amounts of $\mathrm{RuCl}_{3}$ and $\mathrm{NaNO}_{2}\left(1: 10\right.$ molar ratio) in aqueous solution at $100{ }^{\circ} \mathrm{C}$ for 1 hour, followed by addition of $\mathrm{H}_{2} \mathrm{PtCl}_{6}$ and cooled to room temperature. Then, the $\mathrm{H}_{2} \mathrm{SO}_{4}$ was added to increase the conductivity of the plating bath. The resulting concentrations for the $\mathrm{Pt}, \mathrm{Ru}$, and $\mathrm{H}_{2} \mathrm{SO}_{4}$ are $5.0 \mathrm{mM}, 5.0 \mathrm{mM}$, and $0.25 \mathrm{M}$, respectively. Figure 1 provides the illustration for the pulse parameters including $\mathrm{T}_{\text {on }}=50 \mathrm{~ms}, \mathrm{~T}_{\mathrm{off}}=200 \sim 500 \mathrm{~ms}, \mathrm{~J}_{\mathrm{A}}=50$ $\mathrm{mA} / \mathrm{cm}^{2}$, and total coulomb charge of $8.0 \mathrm{C} / \mathrm{cm}^{2}$.

Electrochemical measurements were conducted at room temperature in a three-electrode arrangement using an EG\&G 263A. Cyclic voltammetric analysis (CV) was taken in a potential range of -0.2 and $0.9 \mathrm{~V}$ at a scan rate of $20 \mathrm{mV} / \mathrm{s}$ in solutions of $0.5 \mathrm{M} \mathrm{H}_{2} \mathrm{SO}_{4}$ (for hydrogen absorption/desorption), as well as $0.5 \mathrm{M} \mathrm{H}_{2} \mathrm{SO}_{4}$ and $1 \mathrm{M}$ $\mathrm{CH}_{3} \mathrm{OH}$ (for methanol oxidation).

Figure 2 exhibits the XRD pattern for the as-deposited PtRu where a single diffraction peak at $41^{\circ}$ was present. From the JCPDS data, the Pt exists in a fcc phase with the (111) peak at $39.8^{\circ}$. Since the atomic size of $\mathrm{Ru}$ is smaller than that of $\mathrm{Pt}$, alloying of $\mathrm{Ru}$ into the Pt lattice is expected to reduce the latter's lattice parameter. This explains the observed slight shift of the diffraction peak (111) into higher angles. The $\mathrm{XRD}$ result suggested alloying of $\mathrm{Pt}$ and $\mathrm{Ru}$ was achieved successfully.

Figure 3(A) provides the CV scans for the as-prepared PtRu nanoparticles in $0.5 \mathrm{M}$ $\mathrm{H}_{2} \mathrm{SO}_{4}$ electrolyte at $\mathrm{T}_{\text {off }}$ of $200,300,400$, and $500 \mathrm{~ms}$, respectively. Earlier, it was established that the characteristic peak for the hydrogen adsorption and desorption at $\mathrm{Pt}$ surface appeared in the potential range of -0.12-0.02 V [7-10]. However, in the case of $\mathrm{PtRu}$, the oxidation of $\mathrm{Ru}$ into $\mathrm{RuO}_{\mathrm{x}} \mathrm{H}_{\mathrm{y}}$ was taking place concurrently and thus the $\mathrm{CV}$ responses became rather broad. As expected, we observed broad CV profiles from all samples. In particular, the curve from $\mathrm{T}_{\text {off }}$ of $400 \mathrm{~ms}$ exhibited the largest current value. 
Since the area underneath the CV scans also reflects the effective electrochemical surface area, we surmised $\mathrm{T}_{\text {off }}$ of $400 \mathrm{~ms}$ to be of great interest among all our samples.

Figure 3(B) demonstrates the $\mathrm{CV}$ curves in $0.5 \mathrm{M} \mathrm{H}_{2} \mathrm{SO}_{4}$ and $1 \mathrm{M} \mathrm{CH}_{3} \mathrm{OH}$. These $\mathrm{CV}$ profiles provide critical information including the onset potentials, forward/backward peak current $\left(i_{f}\right)$, and the ratio of forward peak current to backward peak current $\left(i_{f} / i_{b}\right)$. These values are listed in Table I along with the information on particle sizes (from TEM) and $\mathrm{Pt}$ ratios (from ICP-MS). In methanol oxidation, these recorded CV curves demonstrated typical characteristics of $\mathrm{PtRu}$, i.e., they were consistent with what have been reported in literature [11-13]. Interestingly, the sample for $\mathrm{T}_{\text {off }}$ of $400 \mathrm{~ms}$ revealed the highest ability for the methanol oxidation. For the onset potentials, samples with higher $\mathrm{Ru}$ ratios exhibited lower values. This behavior is understandable because the $\mathrm{Ru}$ atom not only is prone to oxidation in the electrolyte itself but also promotes oxidation of $\mathrm{CO}$ at $\mathrm{Pt}$ surface. Thus excess presence of $\mathrm{Ru}$ produces lower onset potentials for oxidation signals. Figure 4(a) exhibits the effect of $\mathrm{T}_{\text {off }}$ over the resulting Pt amount and specific $i_{b}$ (defined as the absolute value of the cathodic peak current) in the PtRu nanoparticles. It can be seen that the amount of Pt and specific $i_{b}$ increased with larger $\mathrm{T}_{\text {off. }}$ The values for mass activity and $\mathrm{i}_{\mathrm{f}} / \mathrm{i}_{\mathrm{b}}$ are also provided in Fig. 5(b). In literature, the mass activity reflects the intrinsic catalytic ability of an electrocatalyst while the ratio of $\mathrm{i}_{\mathrm{f}} / \mathrm{i}_{\mathrm{b}}$ indicates the tendency of efficient removal of adsorbed $\mathrm{CO}$ at the Pt sites $[12,13]$. Once again, we observed the highest values for samples with $\mathrm{T}_{\text {off }}$ of $400 \mathrm{~ms}$, indicating the highest catalytic ability for the methanol oxidation. Our results were consistent and reliable confirming the superiority of samples with $\mathrm{T}_{\text {off }}$ of $400 \mathrm{~ms}$.

The images from samples with $\mathrm{T}_{\text {off }}$ of 200 and $400 \mathrm{~ms}$ are shown in Fig. 5. Apparently, the sample with $\mathrm{T}_{\text {off }}$ of $400 \mathrm{~ms}$ demonstrated better distributions of fine PtRu particles. In contrast, there was moderate aggregation occurring for sample with $\mathrm{T}_{\text {off }}$ of $200 \mathrm{~ms}$. The difference in the PtRu sizes and distribution might explain the observed superiority in samples with $\mathrm{T}_{\text {off }}$ of $400 \mathrm{~ms}$.

In summary, we successfully demonstrated the growth of PtRu nanoparticles on carbon clothes by a pulse electrodeposition technique. By varying the durations for $\mathrm{T}_{\text {off }}$, we were able to produce PtRu in various compositions and particle sizes. We determined that a $\mathrm{T}_{\text {off }}$ of $400 \mathrm{~ms}$ produced nanoparticles with the highest catalytic ability for the methanol oxidation. The sizes for the PtRu was in 4-20 nm range while its composition was $\mathrm{Pt}_{64} \mathrm{Ru}_{36}$. In addition, the measured mass activity was approximately $213 \mathrm{~mA} / \mathrm{mg}$. We also observed that a shorter $\mathrm{T}_{\text {off }}$ resulted in lower catalytic abilities.

\section{Acknowledgments}


Financial support from the National Science Council of Taiwan is highly appreciated (NSC-96-2221-E-009-110). Equipment loans from Professor George Tu of National Chiao Tung University is noted.

\section{REFERENCES}

1. H. Liu, C. Song, L. Zhang, J. Zhang, H. Wang, and D. P. Wilkson, J. Power Sources, 155, 95 (2006).

2. T. J. Schmidt, M. Noeske, H. A. Gasteiger, R. J. Behm, P. Britz, and H. Bönnemann, J. Electrochem. Soc., 145, 925 (1998).

3. T. J. Schmidt, M. Noeske, H. A. Gasteiger, R. J. Behm, P. Britz, W. Brijoux, and H. Bönnemann, Langmuir, 13, 2591 (1997).

4. C. Coutanceau, A. F. Rakotondrainibe, A. Lima, E. Garnier, S. Pronier, J-M. Léger, and C. Lamy, J. Appl. Electrochem., 34, 61 (2004).

5. F. Alcaide, Ŏ. Miguel, and H-J. Grande, Catal. Today, 116, 408 (2006).

6. Z. D. Wei, S. G. Chen, Y. Liu, C. X. Sun, Z. G. Shao, and P. K. Shen, J. Phys. Chem. C, 111, 15456 (2007).

7. E. Antolini and F. Cardellini, J. Alloy Compd., 315, 118 (2001).

8. A. Wieckowski, E. R. Savinova, and C. G. Vayenas, Catalysis and Electrocatalysis at Nanoparticle Surfaces (2003).

9. E. A. Ticcianelli, J. G. Beery, M. T. Paffet, and S. Gottesfeld, J. Electroanal. Chem., 258, 61 (1989).

10. F. Richarz, B. Wohlmann, U. Vogel, H. Hoffschulz, and K.Wandelt, Surf. Sci., 335, 361 (1995).

11. M. T. Tsai, T. K. Yeh, and C. H. Tsai, Electrochem. Comm., 8, 1445 (2006).

12. R. Manohara and J. B. Goodenough, J. Mater. Chem., 2, 875 (1992).

13. Z. Liu, X. Y. Ling, X. Su, and J. Y. Lee, J. Phys. Chem. B, 108, 8234 (2004). 


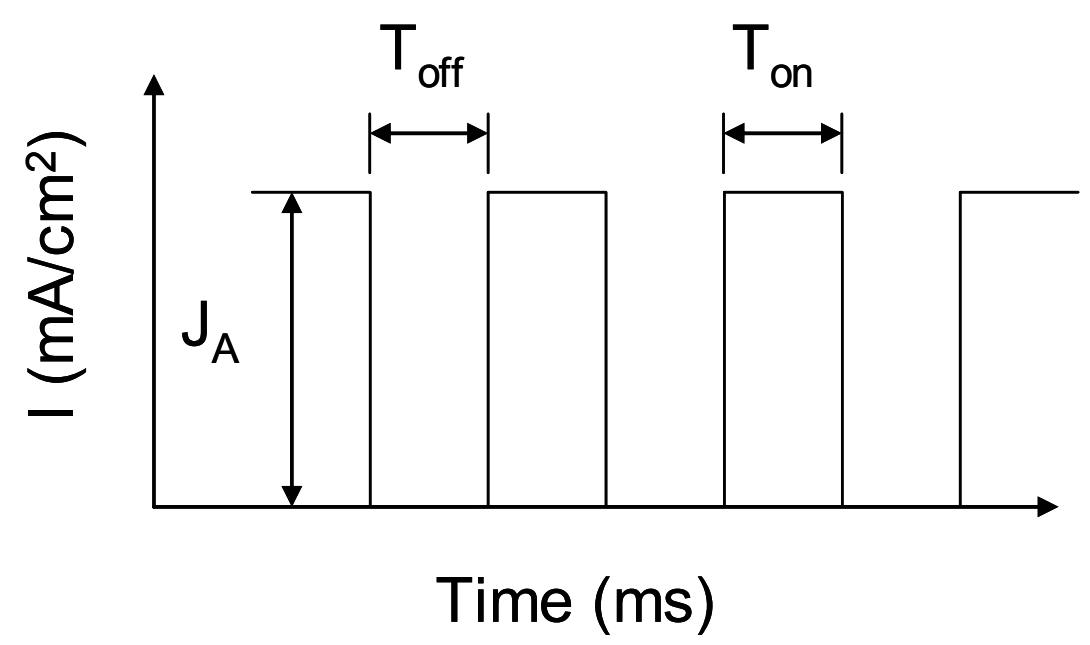

Figure 1: Illustration of parameters used in the pulse galvanostatic electrodeposition.

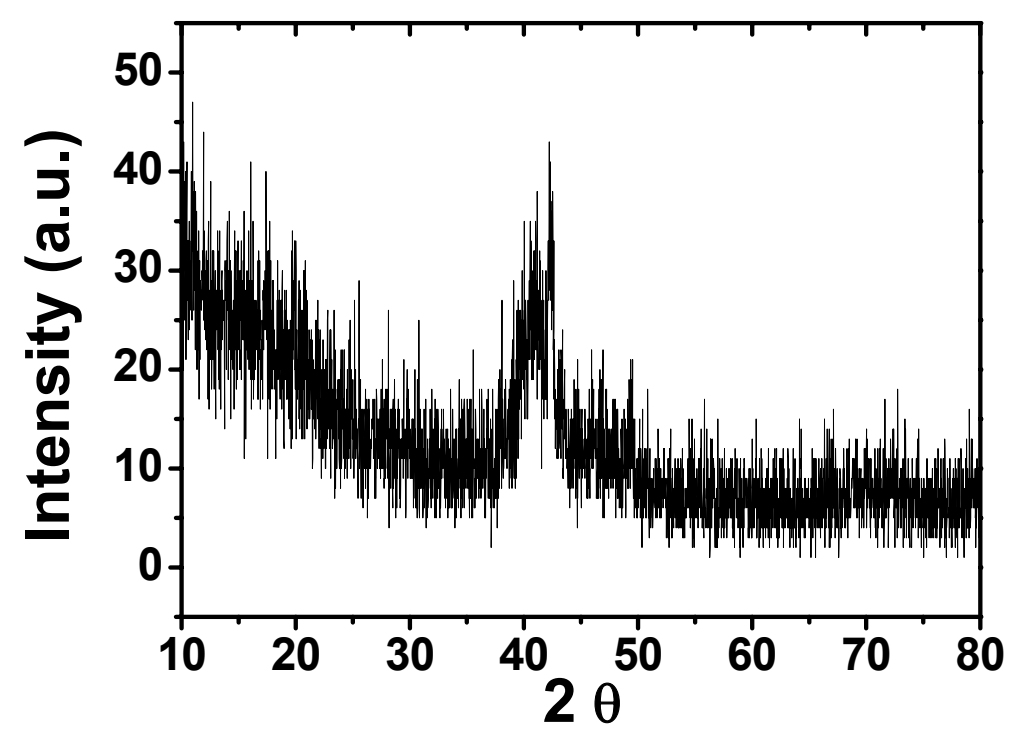

Figure 2: The XRD pattern of electrodeposited PtRu on a $\mathrm{Cu}$ substrate. 

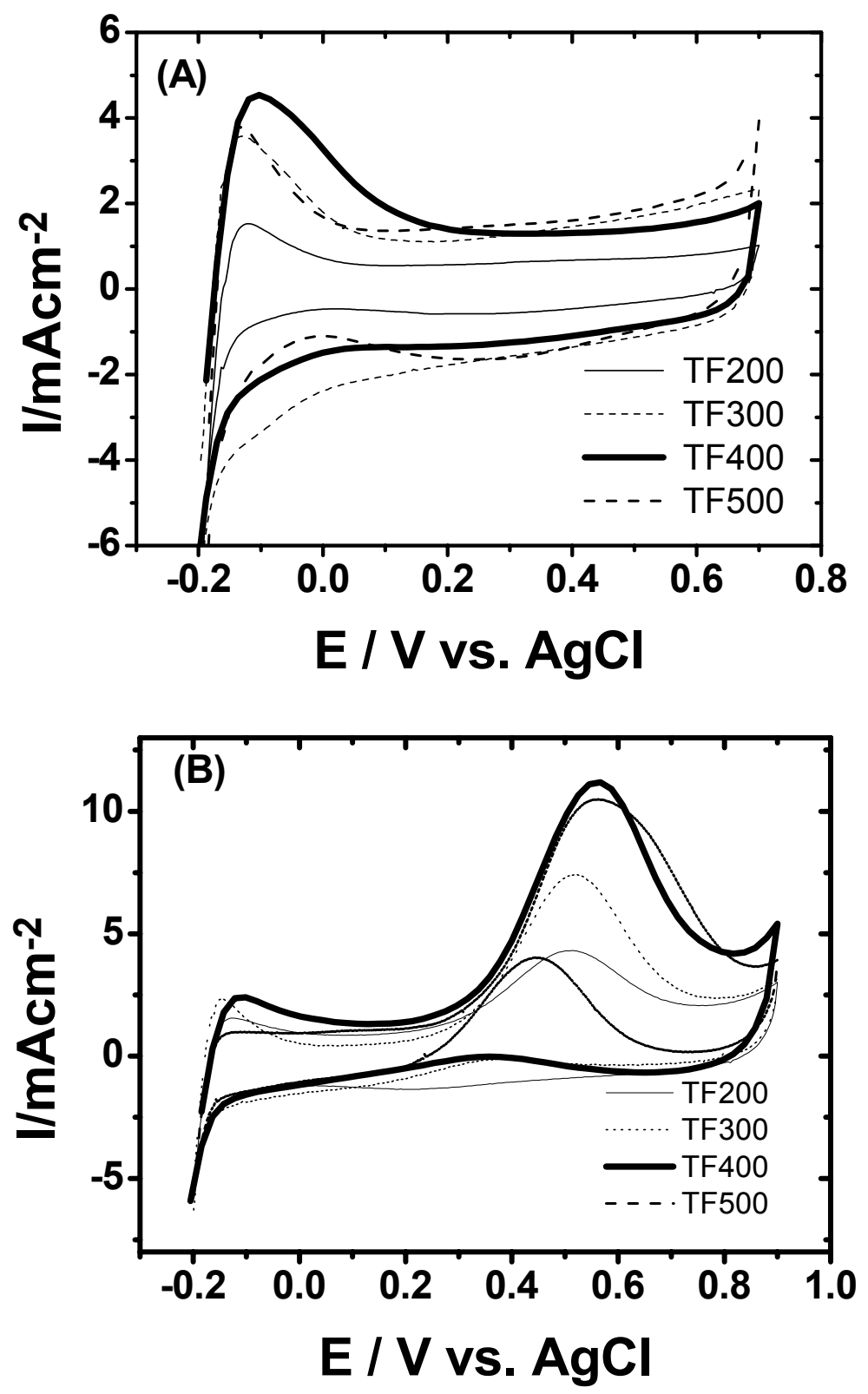

Figure 3: Cyclic voltammograms of PtRu electrocatalysts deposited with various $\mathrm{T}_{\text {off }}$ (labeled as TF in the diagrams, unit in $\mathrm{ms}$ ) in electrolyte of (A) $0.5 \mathrm{M} \mathrm{H}_{2} \mathrm{SO}_{4}$, as well as (B) $0.5 \mathrm{M} \mathrm{H}_{2} \mathrm{SO}_{4}$ and $1.0 \mathrm{M} \mathrm{CH}_{3} \mathrm{OH}$. 

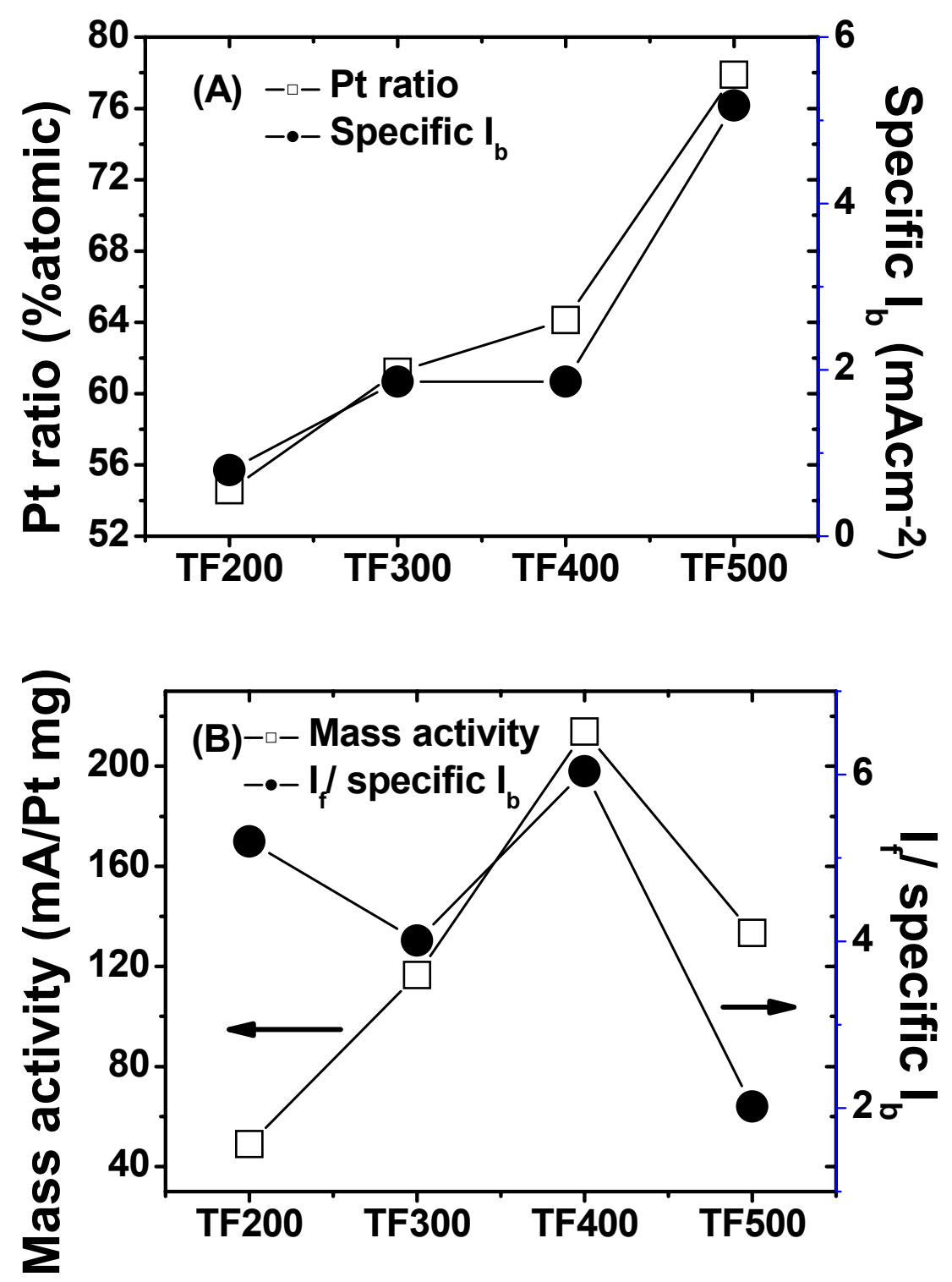

Figure 4: Relations of CV parameters with various $\mathrm{T}_{\text {off }}$ (labeled as $\mathrm{TF}$, unit in $\mathrm{ms}$ ); (A) specific $I_{b}$ and Pt ratio, as well as (B) mass activity and $I_{f} / I_{b}$. 

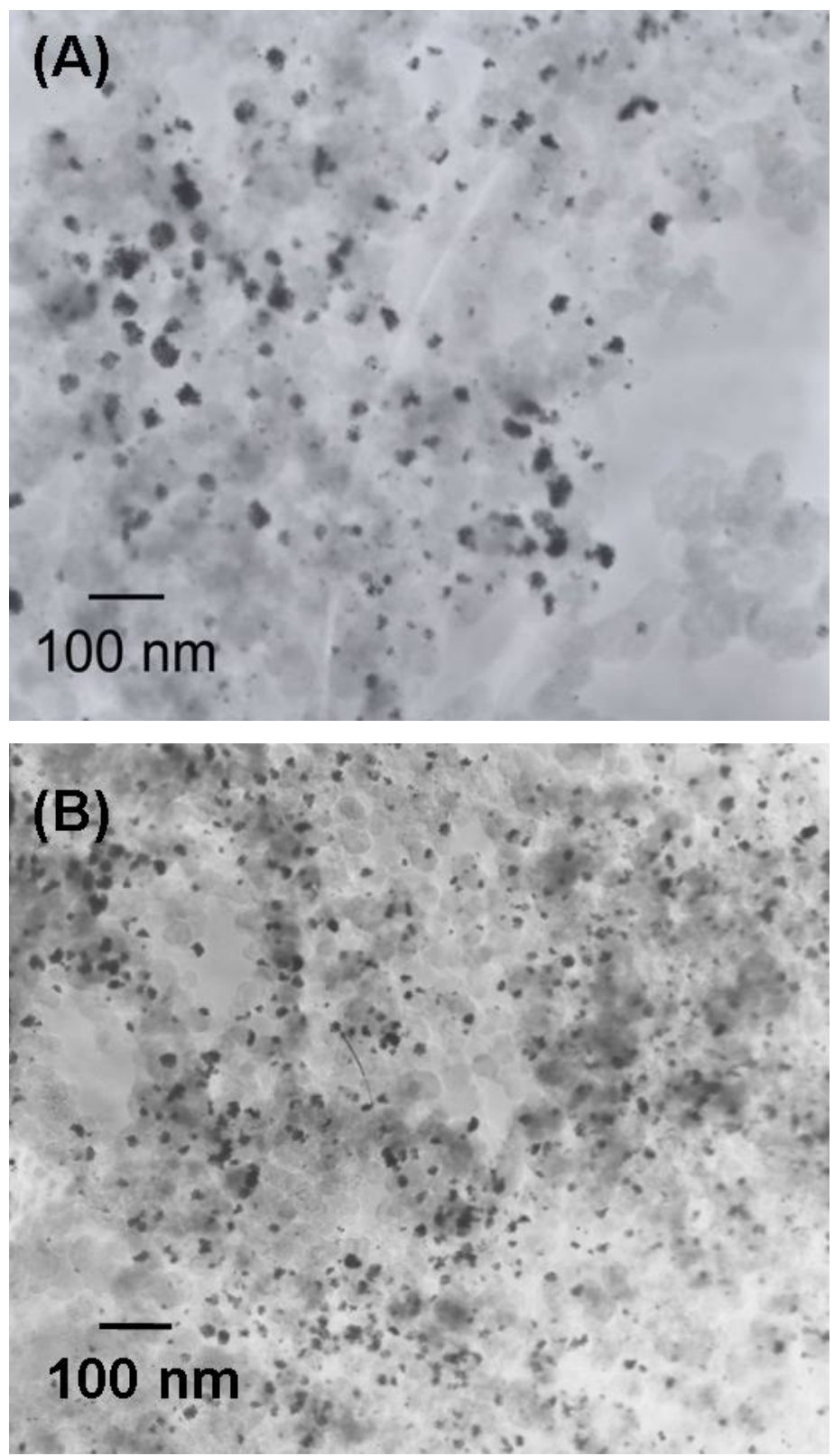

Figure 5: The TEM images for PtRu nanoparticles prepared with (a) $\mathrm{T}_{\text {off }}$ of $200 \mathrm{~ms}$, and (b) $\mathrm{T}_{\text {off }}$ of $400 \mathrm{~ms}$, respectively. 
Table I. Materials information of PtRu from various $T_{\text {off }}$ (labeled as TF).

\begin{tabular}{|c|c|c|c|c|c|c|c|}
\hline \multirow[b]{2}{*}{$\begin{array}{c}\text { Parameter } \\
\text { (in ms) }\end{array}$} & \multirow[b]{2}{*}{$\begin{array}{c}\text { Pt } \\
\text { Atomic \% }\end{array}$} & \multirow[b]{2}{*}{$\begin{array}{c}\text { Total weight } \\
\left(\mathrm{mgcm}^{-2}\right)\end{array}$} & \multirow[b]{2}{*}{$\begin{array}{l}\text { Onset potential } \\
\text { (V vs. } \mathrm{AgCl})\end{array}$} & \multicolumn{2}{|c|}{ Mass activity } & \multirow[b]{2}{*}{$\begin{array}{l}\text { Particle } \\
\text { size(nm) }\end{array}$} & \multirow[b]{2}{*}{$i_{\mathrm{f}} / i_{\mathrm{b}}$} \\
\hline & & & & $\begin{array}{c}\mathbf{m A} / \mathbf{P t} \\
\mathbf{m g}\end{array}$ & $\begin{array}{c}\text { mA/PtRu } \\
\text { mg }\end{array}$ & & \\
\hline TF200 & 54.6 & 0.129 & 0.106 & 48.9 & 34.2 & $8-32$ & 5.20 \\
\hline TF300 & 61.2 & 0.085 & 0.135 & 116.5 & 87.7 & na & 4.01 \\
\hline TF400 & 64.1 & 0.068 & 0.167 & 213.8 & 165.8 & $4-20$ & 6.04 \\
\hline TF500 & 77.9 & 0.091 & 0.217 & 133.4 & 116.3 & na & 2.02 \\
\hline
\end{tabular}

